\title{
RES JUDICATA AND THE CONTINUING CAUSE OF ACTION: A NEW PITFALL FOR THE PRIVATE ANTITRUST PLAINTIFF*
}

THE doctrine of res judicata ${ }^{1}$ bars subsequent litigation of any part of a "cause of action" which has once proceeded to judgment on the merits." Where the prior action was founded upon a single transaction or occurrence, a later suit alleging similar transactions or occurrences subsequent to judgment is clearly not based upon the original cause of action. ${ }^{3}$ However, a private antitrust action ${ }^{4}$ is often founded upon a course of business con-

*Lawlor v. National Screen Service Corp., 211 F.2d 934 (3d Cir.), affirming 1953 Trade CAS. $\{67,619$ (E.D. Pa. 1953), cert. granted, 75 Sup. Ct. 42 (1954).

1. The term "res judicata" is used in this Note as in 1 Moore, Federal Practice \$2.044 (Cum. Supp. 1942), exclusively to denote the effect of a judgment on the merits as an absolute bar to subsequent litigation between the same parties, or those in privity with them, upon the same claim or demand. The term "collateral estoppel" is used to denote the conclusive effect of a judgment upor issues of fact, or mixed fact and law, actually litigated and necessarily determined by the court, called "estoppel by jutdgment" by Moore. Ibid.

The terminology of the law of judgments has been chaotic. "Res judicata" as defined above includes the effects of a judgment sometimes referred to as "bar," "merger," and "the rule against splitting a cause of action." For definitions of these terms see RESTATEMENT, JudGMents $\$ \$ 47,48,62$ (1942). But "res judicata" is sometimes used as a broad generic term for all the conclusive effects of a judgment, encompassing both the above concepts and "collateral estoppel." Id. at 160; Developments in the Lan-Res Judicata, 65 HARv. L. REv. 818, 820 n.I (1952).

"Collateral estoppel" as defined above is synonymous with the terms "estoppel by judgment," "estoppel by record," and "estoppel by verdict," as ordinarily used. See 1 Moore, op. cit. supra, at 115 n.3a; Bigelow, Estoppel 27 (2d ed. 1876) ; Millar, The Historical Relation of Estoppel by Record to Res Judicata, 35 ILt. L. Rev. 41 (1940).

2. Reed v. Allen, 286 U.S. 191 (1932) ; Baltimore S.S. Co. v. Phillips, 274 U.S. 316 (1927) ; Williamson v. Columbia Gas \& Electric Corp., 186 F.2d 464 (3d Cir. 1950), cert. denied, 341 U.S. 921 (1951). See also 2 FreEMan, JudGuents $\$ \$ 546,676$ (5th ed. 1925) ; 1 Moore, op. cit. supra note $1, \$ 2.044$; Restatement, Judgments $\$ \$ 47,48$, 62 (1942).

In order to be effective as res judicata, a judgment must be valid, ibid., and final, id. $\S 1$, comments c, d, \& $\S 41$. Judgments are binding only upon the parties to the action, and persons in privity with them. See 1 MOORE, op. cit. supra, \$2.046; RESTATEMENT, JUDGMENTS c. 4 (1942).

3. See Restatement, Jubgments $\$ 61$, comment c (1942). Joinder of claims based on a series of similar transactions or occurrences occurring prior to judgment may, however, be required. See, e.g., Kelly v. Cape Girardeau, 338 Mo. 103, 89 S.W.2d 41 (1935) (recurrent floodings).

4. Suits for treble damages by persons injured in business or property "by reason of anything forbidden in the antitrust laws," are authorized by $\$ 4$ of the Clayton Act. 38 SтAт. 731 (1914), 15 U.S.C. \$15 (1952), superseding similar provisions in the Shcrman Act, 26 Sтат. 210 (1890). Private suits for injunction are authorized by Clayton Act § 16, 38 Stat. 73 (1914), 15 U.S.C. $\$ 26$ (1952). 
duct pursued over a period of years. 5 When such a suit has once gone to judgment, a problem has recently arisen as to whether a subsequent action alleging a continuation of the same course of conduct is based upon the original cause of action and is therefore barred by the prior judgment. ${ }^{\circ}$

Lawlor v. National Screen Service Corp. ${ }^{7}$ held that a prior judgment barred a private antitrust suit based upon continuation of the same course of conduct previously at issue. Lawlor, a local distributor of motion picture advertising accessories, ${ }^{8}$ had brought an action in 1942 for treble damages and an injunction against three motion picture producers and National Screen, a nationwide distributor. ${ }^{9}$ The complaint charged that the defendants

5. Most violations of the Sherman Act, 26 StAT. 209 (1890), 15 U.S.C. $\$ \$ 1-3$ (1952), such as adherence to contracts in restraint of trade, combination, conspiracy, and monopolization, are continuing crimes rather than a series of distinct offenses. See United States v. Trans-Mrissouri Freight Ass'n, 166 U.S. 290, 342 (1S97); United States v. Swift, 186 Fed. 1002 (N.D. Ill. 1911) ; cf. Waters-Pierce Oil Co. v. Tesis, 212 U.S. $86,107-8$ (1909). The criminal statute of limitations does not begin to run on a conspiracy so long as the illegal design has not been abandoned or concluded. United States v. Kissel, 218 U.S. 601, 608 (1910).

The continuing nature of private antitrust causes of action has plagued the courts in connection with civil statutes of limitations, which ordinarily begin to run when the cause of action "accrues." See, generally, Wilson, Origin and Limiled Life of the Antitrust Cause of Action, 21 KaN. City L. Rev. 127 (1953).

6. The effect of prior litigation has seldom been an issue in private antitrust cases. Until recently there had been only a negligible number of such suits. See Comment, 61 YALE L.J. 1010, 1011 (1952).

Van Brode Milling Co. v. Kellogg Co., 113 F. Supp. 845 (D. Del. 1953), held that dismissal of an antitrust counter-claim for failure of prosecution was no bar to a subsequent action alleging later conduct of a similar type. But see United States v. United States Gypsum Co., 51 F. Supp. 613, 622 (D.D.C. 1943) (dictum). See also 103 U. PA. L. REv. 273 (1954).

The extent to which judgment bars subsequent civil actions by the government is by no means clear. Although successive actions involving the same or similar issues have often been brought by the government, res judicata has rarely been urged as a defense. See cases cited in Black, Res Judicata and Conspiracy Cases under the Sherman Aet, $30 \mathrm{Kr}$. L.J. $255,255 \mathrm{n} .1,256 \mathrm{n} .2$ (1942). Moreover, res judicata has been applied less stringently to the federal government than to private plaintiffs. Compare FTC v. Mfotion Picture Advertising Service Co., 344 U.S. 392, 397-9S (1953), ruith Williamson v. Columbia Gas \& Electric Corp., 186 F.2d 464, 468 (3d Cir. 1950), cert. denied, 341 U.S. 921 (1951). Even if res judicata were upheld, the government would not be precluded from bringing a criminal action. Civil judgments have no res judicata effect in criminal actions, and vice versa. 1 Moore, Federal Practice $\$ 2.047$ (Cum. Supp. 1942). Collateral estoppel applies, however, and might defeat a subsequent civil or criminal action. Ibid.; Lugar, Criminal Law, Donble Jeopardy and Res Iudicata, 39 Iowa L. REv. 317 (1954).

7. 211 F.2d 934 (3d Cir.), cert. granted, 75 Sup. Ct. 42 (1954).

8. Lawlor distributed only "standard" accessories, such as photographs and posters, used for display advertising in theatres. Id. at 935; Brief for Appellants, pp. 2-3, Lawlur v. National Screen Service Corp., 211 F.2d 934 (3d Cir. 1954).

9. Lawlor v. National Screen Service Corp., 211 F.2d 934, 935 (3d Cir. 195t). National Screen, in addition to distributing "standard" accessories, distributed film trailers and "specialty" accessories. Ibid. 
had conspired since 1940 to monopolize the national market in copyrighted motion picture advertising accessories by means of exclusive distribution licenses. ${ }^{10}$ This suit was settled in 1943.11 Lawlor executed a general release, ${ }^{12}$ and received in return a contract to purchase standard accessories from National Screen for resale in the Philadelphia area. ${ }^{13}$ Julgment of dismissal with prejudice was then entered by stipulation of the parties. ${ }^{14}$ In 1949, Lawlor brought a second action against the same defendants and five other motion picture producers, alleging that the conspiracy had continued, ${ }^{15}$ and that the other producer-defendants had joined the conspiracy by signing exclusive distribution licenses with National Screen after the 1943 judgment was entered. ${ }^{16}$ The complaint demanded an injunction and treble damages for the period 1943-1949.17

The Third Circuit ruled that the prior consent judgment barred Lawlor's subsequent claims against all nine defendants. ${ }^{18}$ Noting that the subsequent acts were done in furtherance of the original conspiracy and constituted "essentially the same course of wrongful conduct" alleged in the prior action, the court concluded that Lawlor's second suit was based upon the same cause of action previously asserted, and was therefore barred by res judicata. ${ }^{19}$ Moreover, the relationship between the defendants was "close enough" to entitle the five motion picture producers not parties to the prior action

10. Lawlor v. National Screen Service Corp., 1953 Trade CAS. $\llbracket 67,619$, p. 68,951 (E.D. Pa. 1953).

11. Lawlor v. National Screen Service Corp., 211 F.2d 934, 935 (3d Cir. 1954).

12. Lawlor v. National Screen Service Corp., 1953 Trade CAs. $\llbracket 67,619$, p. 68,951 (E.D. Pa. 1953). The release covered only accrued claims. Brief for Appellants, p. 6, Lawlor v. National Screen Service Corp., 211 F.2d 934 (3d Cir. 1954).

13. Ibid.

The defendants argued that Lawlor was estopped by its adherence to the contract with National Screen, Brief for Appellees, pp. 13-16, Lawlor v. National Screen Scrvice Corp., 211 F.2d 934 (3d Cir. 1954), but this contention was never adjudicated. On the effect of equitable defenses in private antitrust suits, see Kiefer-Stewart Co. v. Joseph E. Seagram \& Sons, Inc., 340 U.S. 211 (1951) (unclean hands); Note, 48 Nw. L. Rev. 619 (1953).

14. Lawlor v. National Screen Service Corp., 211 F.2d 934, 935 (3d Cir. 1954).

Lawlor's contention that its earlier suit was settled under duress was rejected both by the district court and the Third Circuit. See Lawlor v. National Screen Service Corp., 1953 TrAdE CAS. $\{67,619$, p. 68,954 (E.D. Pa. 1953), aff'd, 211 F.2d 934 (3d Cir. 1954). But see Ring v. Spina, 148 F.2d 647, 652-54 (2d Cir. 1945).

15. Id. at $935,936-37$.

16. Lawlor v. National Screen Service Corp., 1953 Trade Cas. $\| 67,619$, p. 68,952 (E.D. Pa. 1953). See also Brief for Appellants, supra note 12, at 4-7.

17. Lawlor v. National Screen Service Corp., 211 F.2d 934, 935 (3d Cir. 1954).

18. Id. at $936-37$.

19. Id. at 934-36. The court nowhere made the statement that the same cause of action was involved in the two actions. It did, however, state unequivocally that plaintiffs could be barred only if they were "suing upon the 'same cause of action' as that upon which they sued in 1942," id. at 935, and then held that plaintiffs were barred, id. at 936-37. 
to the benefit of the judgment even though they were not in privity with the original defendants. ${ }^{20}$

The phrase "essentially the same course of wrongful conduct" appears to have been used in a remarkably broad sense. Although four of the 1949 defendants had been parties to the original conspiracy ${ }^{21}$ and the exclusive licenses and monopolized market were the same in both actions, 22 five additional defendants had joined the conspiracy and thereby increased its market power from approximately sixty-seven per cent in 19.2 to almost one hundred per cent in 1949.23 And while the principal charge in 1942 was that the defendants' exclusive arrangements denied Lawlor access to normal sources of supply of standard accessories, ${ }^{24}$ the principal charge in 1949 was that National Screen had deliberately made slow and erratic deliveries of accessories under its contract with Lawlor, and that the defendants had used tie-in sales and other means of exploiting their power in related markets to monopolize the market for standard accessories. ${ }^{25}$ Furthermore, the exclusive licenses and tie-in sales effected after 1943 were acts constituting independent violations of the antitrust laws, whether or not done pursuant to the original conspiracy. ${ }^{2 B}$

20. Id. at 937 .

21. Id. at 935 .

22. Lawlor v. National Screen Service Corp., 1953 Trane Cas. \67,619, p. 68,952 (E.D. Pa. 1953).

23. Compare Complaint, para. 48, Allied Poster \& Supply Corp. v. National Screen Service Corp., Civil No. 2472 (E.D. Pa. 1942) (60-73\% of national accessories market), with Lawlor v. National Screen Service Corp., 99 F. Supp. 1S0, 1S4 (E.D. Pa. 1951) (virtually $100 \%$ market control). Thus, even if the 1943 judgment had represented a determination that defendants' conduct was not illegal in view of their market position at that time, it would not be controlling as to the legality of defendants' conduct in 1949. See United States v. Columbia Steel Co., 334 U.S. 495, 527-28 (1948); United States v. Aluminum Co., 148 F.2d 416, 424 (2d Cir. 1945).

Since Lawlor was decided on a motion to dismiss, it is proper to assume that the allegations of the complaint were true. See Clark v. Uebersee Finanz-Korporation, 332 U.S. 480 (1947) ; Kingwood Oil Co. v. Bell, 204 F.2d 8 (7th Cir. 1953).

24. Complaint, paras. 34, 35, 46, Allied Poster \& Supply Corp. v. National Screen Service Corp., Civil No. 2472 (E.D. Pa. 1942). Price discrimination, use of exclusive dealing contracts, monopolization, and conspiracy to monopolize were also charged in 1942. Id., passin.

25. Amended Complaint, paras. 35-47, Lawlor v. National Screen Service Corp., 1953 Trade CAs. $\{67,619$ (E.D. Pa. 1953). After the settlement agreement of 1943, plaintiffs could buy standard accessories from National Screen, see note 13 ssspra, but National Screen retained exclusive control over the distribution of "specialty" accessories and "trailers." Amended Complaint, supra, paras. 31, 39.

26. The five exclusive agreements signed after judgment were probably independent violations of $\$ 3$ of the Clayton Act, United States v. Standard Oil Co. of California, 337 U.S. 293, 314 (1949), and might have amounted to violations of $\$ 1$ of the Sherman Act, United States v. Socony-Vacuum Oil Co., 310 U.S. 150, 226 n.59 (1948), particularly since defendants' market power had increased, United States v. United Shoe Mlachinery Corp., 110 F. Supp. 295, 343 (D. Mass. 1953), aff'd per curian, 346 U.S. 894 
The problem of determining whether res judicata precludes successive actions for continued maintenance of the same condition has arisen in connection with continuing nuisances. If the nuisance is "permanent," plaintiff's past and future damages are immediately ascertainable, and must be recovered in a single action. ${ }^{27}$ Continued maintenance of a permanent nuisance is not a legal wrong, since a nuisance is not "permanent" unless defendant has a legal or equitable right to maintain the condition, once it is created, or unless plaintiff chooses to treat the condition as permanent. ${ }^{28}$ If the nuisance is "temporary" or "abatable," however, a plaintiff may bring stuccessive actions for damages as they accrue. ${ }^{29}$ A fresh wrong is committed every instant that the defendant continues to maintain the offending condition, since the defendant is considered to have a continuing duty to abate the nuisance. ${ }^{30}$ Lawlor treated a conspiracy as a "permanent" wrong which, once attacked, could be continued with impunity. The court dismissed the nuisance cases as too confused to be a helpful analogy. ${ }^{81}$ But the confusion

(1954). Individual tie-in sales constitute per se violations of $\S 1$ of the Sherman Act and $\S 3$ of the Clayton Act. International Salt Co. v. United States, 332 U.S. 392 (1947); cf. Fashion Originators' Guild v. FTC, 114 F.2d 80 (2d Cir. 1940), aff'd, 312 U.S. 457 (1941). Therefore the fact that the "same" conspiracy was charged in both actions seems immaterial, since plaintiffs need not have alleged conspiracy in order to state valid claims against the defendants.

27. E.g., Missouri Pac. R.R. v. McGuire, 205 Ark. 658, 169 S.W.2d 872 (1943); Stodghill v. The Chicago, B. \& Q.R.R., 53 Iowa 341, 5 N.W. 495 (1888); Bruton v. Carolina Power \& Light Co., 217 N.C. 1, 8-9, 6 S.E.2d 822, 826-27 (1940). See also Clark, Code Pleading 486-8 (2d ed. 1947); Goodrich, Permanent Structures and Contimuing Injuries, the Iowa Rule, 4 Iowa L. Bull. 67 (1918); McCormick, Damages for Anticipated Injary to Land, 37 Harv. L. Rev. 574 (1924).

28. See Goodrich, supra note 27 , at 79 ; McCormick, supra note 27 , at $584-89$; RESTATENIENT, ToRTS $\S 930$ (1939). This rule, which centers about whether the nuisance is enjoinable, is the better and more usual one. Under the minority rule, the test is whether the nuisance is physically permanent, and no inquiry is made as to whether or not it is legally abatable. See Troy v. Cheshire R.R., 23 N.H. 83 (1851); Powers v. Council Bluffs, 45 Iowa 652 (1877); Goodrich, supra note 27, at 69-76.

Judgment in an action on a permanent nuisance confers upon the defendant a right to continue to maintain the offending condition. See, e.g., Mansfield v. Tenney, 202 Mass. 312, 88 N.E. 892 (1909); Vanderslice v. Irondale Electric Light, Heat \& Power Co., 232 Pa. St. 435, 81 Atl. 445 (1911); Restatedent, Torts $\$ 930$, comment c (1939).

29. Kelly v. Cape Girardeau, 338 Mo. 103, 89 S.W.2d 41 (1935) (abatable); City of Holdenville v. Kiser, 195 Okla. 189, 156 P.2d 363 (1945) (temporary); Nelson v. Consolidated Sand \& Stone Co., 66 S.D. 357, 283 N.W. 164 (1938) ("recurrent"). See also secondary sources cited note 27 supra. The offending condition is temporary if it is not one which will continue indefinitely, so that prospective damages cannot be assessed with accuracy. It is abatable if it is a condition which could be enjoined at plaintiff's instance. In both types of cases, successive actions may be brought for damages as they accruc. See Restatement, Torts \$930, comments a, b (1939).

30. Kelly v. Cape Girardeau, 338 Mo. 103, 89 S.W.2d 41 (1935); Nelson v. Consolidated Sand \& Stone Co., 66 S.D. 357, 283 N.W. 164 (1939); Nashville v. Comer, 88 Tenn. 415, 12 S.W. 1027 (1890). See also McCormick, supra note 27, at 593.

31. Lawlor v. National Screen Service Corp., 211. F.2d 934, 936 (3d Cir. 1954). An- 
in nuisance cases has arisen in determining whether a particular condition was "permanent" or "abatable,"32 not as to whether successive actions could be brought for an admittedly wrongful course of conduct pursued after judgment. ${ }^{33}$ Violations of the antitrust laws are explicitly declared "abatable" by statute. ${ }^{34}$ And continued participation in a conspiracy after judgment is a new offense which will support a separate indictment and conviction. ${ }^{35}$

A cause of action has been defined as "the operative facts" the basis for the claim or demand, or alternatively as "the legal wrong which the facts show." 37 All the operative facts constituting the legal wrongs alleged in Lawlor's 1949 complaint came into existence after the 1943 judgment, and therefore could not have been advanced as grounds for relief in the earlier action. ${ }^{38}$ Moreover, none of the relief sought in 1949 was claimed for the defendants' conduct prior to $1943 .^{30}$ The Third Circuit thus appeared

other analogy which the court might have considered is that of the installment contract. Where a partial breach of contract is accompanied by a repudiation, plaintiff may bring only one action for damages in many jurisdictions. E.g., Palkas v. Hollingshead, 184 N.Y. 211, 77 N.E. 40 (1906); Chapman v. Potomac Chemical Co., 159 F.2d 459 (D.C. Cir. 1947) ; Smith \& Gottlieb, Inc. v. Cheatham, 31 A.2d 676 (D.C. Mun. Ct. App. 1942) ; Clark, Code Pleading $472-79$ (2d ed. 1947) ; Comment, 64 Yale L.J. 85, 114-18 (1954). Where there is no effective repudiation, defendant remains under a duty to carry out the contract, and subsequent actions will lie for subsequent breaches. Sce 4 Corbin, ContRacts $\$ 954$ (1951); Bennett, The Modern Lcase-An Eslate in Land or a Contract, 16 TEx. L. Rev. 47 (1938). The contract analogy, like the nuisance analogy, would lead to the conclusion that successive actions should be permitted, since defendant could hardly be considered to have repudiated his future obligations to plaintiff under the antitrust laws.

32. See note 27 supra.

33. In cases where a nuisance is created by illegal activity, or the wrongiul or negligent maintenance of a lawful structure, the nuisance is always "abatable." See Uline v. New York Cent. \& H.R.R., 101 N.Y. 98, 4 N.E. 536 (1886); Milan v. Bethlehem, $372 \mathrm{~Pa} .598,94$ A.2d 774 (1953) ; Bartlett v. Grasselli Chemical Co., 92 WV. Va. 445, 115 S.E. 451 (1922). See Annot, 1916E L.R.A. 997, 1013-42 (1916).

34. Clayton Act $\$ 16,38$ STar. 737 (1914), 15 U.S.C. $\$ 26$ (1952).

35. United States v. Swift, 186 Fed. 1002 (N.D. Ill. 1911).

36. See Clake, Code Pleadirg $\$ 19$ (2d ed. 1947); 2 Moore, Fedral Practice 378 (2d ed. 1948). Other definitions of a cause of action, see generally CLARK, op. cit. supra, at 476-78; Developments in the Law-Res Judicata, 65 HARv. L. REv. 818, 824-31 (1952), are narrower than the above definition, and would therefore support a fortiori the argument advanced in text.

37. Baltimore S.S. Co. v. Phillips, 274 U.S. 316 (1927). See also American Fire \& Cas. Co. v. Finn, 341 U.S. 6, 13 (1951).

38. See text at notes 15-17 supra. Although Lawlor in his second complaint alleged certain facts in existence prior to 1943, such as the signing of the original contracts, the operative facts centered about defendants' continued adherence to those contracts after judgment. Amended Complaint, paras. 48-50, Lawlor v. National Screen Service Corp., 1953 TRADE CAS. If 67,619 (E.D. Pa. 1953).

39. To the extent that plaintiffs' injuries suffered after judgment were attributable exclusively to events occurring before judgment, damages presumably could not be recovered in the second action. RestateMrent, Jungarents $\$ 62(19+2)$. 
to find the causes of action identical in the two suits merely because of the similarity of legal issues presented. ${ }^{40}$

The definition of cause of action implicit in Lavelor is not erroneous merely because it departs substantially from prior definitions. Courts have long recognized that a single verbal formula may not be adequate in all cases, ${ }^{41}$ and that they must determine the extent of a cause of action pragmatically, having regard to the purpose served by the concept in different situations. ${ }^{42}$ The policy underlying res judicata is to compel litigants to adopt efficient procedural means of seeking relief to which the substantive law may entitle them. ${ }^{43}$ Lawslor goes far beyond the requirements of this policy, and extinguishes claims which did not even exist at the time of the prior action.

The court's failure to perceive that res judicata can bar only claims which should have been presented in a previous action led to its ruling that the prior judgment barred Lawlor's claims against the five producers not parties to the original suit. ${ }^{44}$ Those defendants could not possibly have been joined in the prior action, since they did not enter the conspiracy until after judgment was rendered. ${ }^{45}$ Under Lawlor, a plaintiff may lose claims he had no reason to know would ever exist, against persons who were total strangers to his original action. But the holding in Lawlor would be open to question even if the five defendants could have been made parties in the prior action: there is no privity between joint wrongdoers, and res judicata has never

40. 211 F.2d 934, 936 (3d Cir. 1954). The court admitted that similarity of legal issues was not an adequate test for res judicata where the action was based on a single isolated tort, ibid., but where the legal issues are presented by a continuing course of conduct, it would apparently require only that the conduct be "essentially the same." See notes 21-26 supra, and accompanying text.

41. E.g., United States v. Memphis Cotton Oil Co., 288 U.S. 62, 67-68 (1933); American Fire \& Cas. Co. v. Finn, 341 U.S. 6, 12 (1951). See Clark, Code Plending 137 (2d ed. 1947) ; 1 Moore, Federal Practice 119 (Cum. Supp. 1942).

42. United States v. Memphis Cotton Oil Co., 288 U.S. 62 (1933), discussed in Arnold, The Code "Cause of Action" Clarified by United Statcs Supreme Court, 19 A.B.A.J. 215 (1933) passim; ClARK, op. cit. supra note 41, at 137.

43. See, generally, Clark, Code Pleading 477 (2d ed. 1947) (trial convenience); 4 Corbin, Contracts $\$ 955$ (1951); cf. Schopflocher, What ls a Single Cause of Action for the Purpose of the Doctrine of Res Judicata?, 21 ORE. L. REv. 319, 364 (1942). Courts are ordinarily content to say that a judgment is conclusive as to every matter that was or should have been litigated in the prior action. See, e.g., Cromwell v. County of Sac, 94 U.S. 351, 352-53 (1876) ; Mercoid Corp. v. Mid-Continent Investment Co., 320 U.S. 661. (1944); Baker v. Moody, 204 F.2d 918 (5th Cir. 1953). See also 1 Moose, Federal Practice 116 (.Cum. Supp. 1942).

44. See text at notes. 18,20 supra.

45. See text at note 16 supra. In the 1942 action, Lawlor alleged that National Screen had attempted to negotiate similar contracts with four of the five producers joined as additional defendants in the 1949 action, but no contracts were signed with these producers until some time after the 1943 judgment was rendered. Ibid.; Lawlor v. National Screen Service Corp., 1953 Trade CAS. $\lceil 67,619$, p. 68,952 (E.D. Pa. 1953). 
previously interfered with a plaintiff's right to sue them severally rather than jointly. ${ }^{40}$

The Third Circuit's definition of cause of action in terms of similarity of legal issues is unfortunate because res judicata operates without regard to how legal issues were resolved in a prior action, or whether they were resolved at all, so long as judgment was "on the merits." rendered in favor of either party on any but procedural grounds, including a consent judgment, is "on the merits." 1 Under Lawlor, a plaintiff who proved that a defendant was violating the antitrust laws, but was denied judgment because of failure to prove damages or causation, ${ }^{40}$ would lose not only his accrued claims, but also any right to legal redress for wrongs done him thereafter by the defendant pursuant to the same course of conduct. ${ }^{\text {Do }}$

46. Bigelow v. Old Dominion Copper MI. \& S. Co., 225 U.S. 111, 132 (1912) ; Bomar v. Keyes, 162 F.2d 136, 140 (2d Cir. 1947); Clark, Cone Pleadiwg 376 (2d ed. 1947); RESTATEMIENT, JUDGATENTS § 94, comment b (1942).

Both the district and circuit courts in Lawlor appear to have confused res judicata and collateral estoppel in connection with the ruling as to parties. Some courts have relaxed the requirement of privity in collateral estoppel cases. See, e.g., Bruszewshi v. United States, 181 F.2d 419 (3d Cir. 1950); Coca-Cola Co. v. Pepsi-Cola Co., 36 Del. 124, 172 Atl. 260 (1934). Relasation of the requirement of privity even in collateral estoppel cases has been criticized. See 1 MLoore, Federal Prictice $\$ 2.047$ (Cum. Supp. 1942) ; Seavey, Res $J_{t}$ dicata with Reference to Persons Neither Parties nor Privies, 57 HARV. L. REV. 98 (1943). Extension of this doctrine to res judicata has apparently never even been advocated. See ClaRk, op. cit. supra, at 479; but cf. 68 HARv. I. REv. 377, 379 (1954). Lawlor in effect makes joinder of defendants compulsory, since apparently a judgment for or against any of them would extinguish claims against the rest. But sce Fre. $R$. Crv. P. 19(a) (joinder required only for indispensable parties). The five new deiendants in Lawlor were not indispensable to the 1942 action. See Wyoge Gas \& Oil Corp. v. Schrack, 27 F. Supp. 35, aff'd on reargument, 29 F. Supp. 582 (M.D. Pa. 1939); 3 Mroone, Federal Practice 2153 (2d ed. 1948).

47. E.g., Reed v. Allen, 286 U.S. 191 (1932) (judgment for plaintiff); Baltimore S.S. Co. v. Phillips, 274 U.S. 316 (1927) (same); United States v. California \& Oregon Land Co., 192 U.S. 355 (1904) (judgment for defendant); Williamson v. Columbia Gas \& Electric Corp., 186 F.2d 464 (3d Cir. 1950), cert. denied, 341 U.S. 921 (1951) (same); Restatenent, Judgarents $\$ 45$ (1942). See also American National Banls \& Trust Co. v. United States, 142 F.2d 571 (D.C. Cir. 1944) (dismissal for failure of prosecution is "on the merits" for purposes of res judicata) ; Van Brode Mfilling Co. v. Kellogs Co., 113 F. Supp. 845 (D. Del. 1953) (same).

48. Id. $\$ 49$, comment a. A consent judgment is "on the merits" for purposes of res judicata. Urbino v. Puerto Rico Ry. Light \& Power Co., 164 F.2d 12 (1st Cir. 1947). Under FED. R. CIV. P. 41(b), any involuntary dismissal on grounds other than lack of jurisdiction or improper venue acts as an adjudication upon the merits, unless the court otherwise specifies in its order.

49. See, e.g., Ring v. Authors' League of America, Inc., 186 F.2d 637 (2d Cir. 1951); Milwaukee Towne Corp. v. Loew's, Inc., 190 F.2d 561, 568 (7th Cir. 1951).

50. Lawlor will affect primarily those plaintiffs who have suffered an adverse judgment, since ordinarily a successful plaintiff would obtain an injunction, and could initiate civil contempt proceedings if defendant continued the same illegal course of conduct. See, e.g., Bigelow v. RKO-Radio Pictures, Inc., 78 F. Supp. 250 (N.D. Ill. 1948), aff'd, 170 F.2d 783 (7th Cir. 1948). 
Presumably even a plaintiff who was awarded damages but failed to obtain an injunction would be helpless thereafter if defendant continued his illegal conduct.51 And plaintiffs who have entered consent judgments after compromising only accrued claims, on the assumption that the antitrust laws would provide a remedy for future violations, have inadvertently compromised more than they intended.52

The interest of individual litigants and the public in preventing vexatious litigation arising from continuing conduct is not protected by res judicata alone. Where an essential issue of fact, or mixed fact and law, has been actually litigated and resolved against the plaintiff in a prior action, stbsequent actions based upon an identical course of conduct by the defendants may be precluded by the doctrine of collateral estoppel..$^{53}$ Thus, if a court has once determined that a defendant's continuing conduct is not unlawful, subsequent actions by the same plaintiff will be barred. ${ }^{\text {t4 }}$ Subsequent

51. A valid, final judgment on the merits awarding damages would extinguish the plaintiff's entire cause of action. 2 FreEMAN, JudgMENTS $\$ 546$ (5th ed. 1925) ; RestuTEMENT, JUDGMENTS $\$ 47$ (1942). In order to obtain an injunction, a private plaintiff must prove that there is a "dangerous probability' of a repetition of the wrong to him individually." Ring v. Authors' League of America, Inc., 186 F.2d 637, 643 (2d Cir. 1951). A plaintiff might be awarded damages but denied an injunction because the threat of future conduct was not imminent enough, or did not endanger him individually, and then, under the Lawolor rule, be denied relief for injury caused by an actual repetition of illegal conduct by defendant. See, contra, Fort Worth Stackyards Co. v. Brown, 161 S.W.2d 549 (Tex. Civ. App. 1942) (prior judgment denying injunction no bar to later action alleging subsequent acts); Wilcher v. Sharpe, 236 N.C. $308,312,72$ S.E.2d 662, 665 (1952) (dictum to same effect); Restatenent, JudGanents $\$ 54$ (1942). In such circumstances a plaintiff might be able to persuade the court to reopen and modify its former judgment pursuant to FED. R. CIv. P. 60(b). See Note, 61 YalE L.J. 76 (1952).

52. Litigants who wish to settle out of court in the future may be able to avoid the effect Lawlor gives to consent judgments by drafting appropriate settlement agreements. Lawolor would probably not preclude a plaintiff from bringing an action for breach of a settlement agreement in which defendant contracted to refrain from engaging in specified similar practices in the future. Moreover, plaintiff could require defendant to contract not to plead the judgment as a bar to actions charging subsequent violations, since res judicata is a waivable defense. See Riordan v. Ferguson, 147 F.2d 983, 987 (2d Cir. 1945); Hill v. Huron, 39 S.D. 530, 165 N.W. 534 (1917). But see von Moschzisker, Res Judicata, 38 Y ALE L.J. 299, 316 (1929).

53. Collateral estoppel makes the decision of a court conclusive in subsequent actions upon the issues actually litigated and necessarily determined, whether or not the same cause of action is involved. Cromwell v. County of Sac, 94 U.S. 351 (1876); Partmar Corp. v. Paramount Pictures Theatres Corp., 347 U.S. 89 (1954). On collateral estoppel generally, see 2 Freenan, Judgments $\$ 689$ (5th ed. 1925); 1 Moore, Feverda Practice $\$ 2.048$ (Cum. Supp. 1942) ; Scott, Collateral Estoppel by Judgmemt, $56 \mathrm{H}$ ARv. L. REv. 1 (1942). See 68 HARv. L. Rev. 377 (1954).

54. See Florasynth Laboratories, Inc. v. Goldberg, 191 F.2d 877 (7th Cir. 1951) (assuming that continued use of tradename by defendant after judgment gave plaintiff new cause of action, prior holding that purchasers would not be misled was conclusive under collateral estoppel) ; Straus v. American Publishers' Ass'n, 201 Fed. 306 (2d Cir. 1912) (judgment conclusive in subsequent antitrust action on issue of legality of defendants' continuing activity); Bodeneck v. Cater's Motor Freight System, Inc, 198 
actions against third parties may be simplified by the doctrine of stare decisis ${ }^{55}$ or precluded by collateral estoppel ${ }^{50}$ where the issues involved have once been litigated and judicially determined against the plaintiff. But the prior judgment in Lawilor, since it was entered by consent, determined no issues either of law or fact. ${ }^{57}$ Although the court recognized that for this reason a consent judgment could have no effect as collateral estoppel, 3 is it nevertheless made this purely formal judgment conclusive as to issues which were neither litigated nor determined.

The decision in Lazilor might seem less objectionable if considered as an extension of res judicata applicable to those cases where plaintiff had an opportunity to litigate not only the legality of a defendant's prior conduct, but also his right to continue that conduct in the future. ${ }^{60}$ Since the plaintiff could have obtained injunctive relief as well as damages in his first action, the public interest in minimizing litigation might seem to justify restricting him to that single opportunity to settle all his claims, both accrued and prospective. ${ }^{60}$ Where an injured plaintiff's rights are freely alienable, as in cases involving nuisance or trespass to land, application of Laulor might be reasonable where a plaintiff voluntarily relinquished his claims to future relief. ${ }^{\circ}$

Wash. 21, \&6 P.2d 766 (1939) (complaint alleging acts by defendant subsequent to judgment stated new cause of action, but prior determination that such acts did not constitute a nuisance was conclusive). But cf. Commissioner v. Sunnen, 333 U.S. 591, 60102 (1948).

55. See 1 Moore, Federal Practice $\$ 2.042$ (Cum. Supp. 1942). The doctrine of stare decisis does not depend on res judicata, and accordingly does not require identity of parties. Jaffe v. FTC, 123 F.2d 814 (7th Cir. 1941). A plaintiff who lost a previous case involving the same subject matter on a ruling of law would often be vulnerable to a motion to dismiss or for summary judgment in a later action against a third party. See discussion in Clank, Code Pleading 554-57, 561 (2d ed. 1947).

56. See authorities cited note 46 supra.

57. A consent judgment has no effect as collateral estoppel, e.g., United States v. International Building Co., 345 U.S. 502 (1953), or as stare decisis, Platt v. Wagner, $347 \mathrm{~Pa} .27,31$ A.2d 499 (1943).

A consent judgment should be distinguished from a consent decree, which is a judicially approved agreement between the contending parties, Swift \& Co. v. United States, 276 U.S. 311 (1928), and from a judgment entered upon stipulated facts, which is fully effective as a pronouncement of law by the court, Kelly v. Town of Mfilan, 21. Fed. 842, 862-63 (C.C.W.D. Tenn. 1884) (dictum), aff'd on other grounds, 127 U.S. 139 (18s8); cf. Florasynth Laboratories, Inc. v. Goldberg, 191 F.2d 877, 880 (7th Cir. 1951) (motion to dismiss).

58. Lawlor v. National Screen Service Corp., 211 F.2d 934, 935 (3d Cir. 1954).

59. See Lawlor v. National Screen Service Corp., 1953 T\&aDz Cas. 167,619, p. 68,953 (E.D. Pa. 1953).

60. Since an injunction may be denied after actual litigation for reasons irrelevant to a future suit, see note 51 stpra, the above policy would seem to be limited to those cases where plaintiff failed to utilize a previous opportunity to obtain prospective relief, as where he compromised his claim for injunction and dismissed his action with prejudice, or where he neglected to make such a claim. But the fairness and effectiveness of this rule are open to serious question in any case. See notes 65 and 66 infra, and accompanying text.

61. In Hahl v. Sugo, 169 N.Y. 109, 62 N.E. 135 (1901), plaintiff's action to enjoin a continuing trespass was held barred by a prior favorable judgment in an action where 
In private antitrust suits, however, allowing waiver of future claims cannot be justified, since it would enable defendants to achieve partial immunity from the antitrust laws. The private antitrust suit was created as a means of public law enforcement. ${ }^{62}$ A release purporting to absolve a defendant from liability for future violations of the antitrust laws, whether or not accompanied by a settlement of future damage claims, would almost certainly be held void as against public policy. ${ }^{63}$ Under Lazelor the same result could be achieved by the simple expedient of filing a complaint and causing it to be dismissed with prejudice. ${ }^{64}$ In cases where a plaintiff's continued commercial existence is dependent upon cessation of a defendant's illegal conduct, Lawlor might provide an additional incentive to a plaintiff to refuse settlement and pursue his claim to injunctive relief, thus perhaps furthering anti-

no injunctive relief was claimed. See also Clark, Code Pleading 475 n.151 (2d cd. 1947) ; 2 Moore, Federal Practice 388-93 (2d ed. 1948). For a contrary view, sec Cleary, Res Judicata Reexamined, 57 Y ALE L.J. 339 (1948) passim. The rule suggested might also be applied in patent and trademark infringement cases, since no public policy forbids alienation of rights in such property. Cf. Addressograph-Multigraph Corp. v. Cooper, 156 F.2d 483, 485 (2d Cir. 1946) (dictum) ; Bresnick v. United States Vitamin Corp., 139 F.2d 239, 242 (2d Cir. 1943) (same).

62. See Bruce's Juices, Inc. v. American Can Co., 330 U.S. 743, 751-52 (1947); Kinnear-Weed Corp. v. Humble Oil \& Refining Co., 214 F.2d 891, 893 (5th Cir. 1954); Maltz v. Sax, 134 F.2d 2, 4 (7th Cir.), cert. denied, 319 U.S. 772 (1943). See also Hammiton \& Tul, Antitrust in Action 10 (TNEC Monograph 16, 1940); Testimony of H. Graham Morison, Hearings before the Subcommittee on Sindy of Monopoly Potucr of the House Committee on the Judiciary on H.R. 3408, 82d Cong., 1st Sess. 15 (1951).

63. Westmoreland Asbestos Co. v. Johns-Mansville Corp., 39 F. Supp. 117 (S.D. N.Y. 1941) (dictum) ; cf. Edward Katzinger Co. v. Chicago Metallic Mfg. Co., 329 U.S. 394, 402 (1947) (covenant not to contest validity of patent uneniorceable); The Ansaldo San Giorgio I v. Rheinstrom Bros. Co., 294 U.S. 494 (1935) (release in advance of carrier's liability for negligent injury to cargo ineffective). See also 5 Williston, Contancts $\S 1652$ n.8 (rev. ed. 1937); 2 id. $\$ 413$ n.5; 103 U. PA. L. Rev. 273 (1954).

64. See 103 U. PA. L. REv. 273 (1954).

Aimost no restriction is imposed upon the right to dismiss an action with prejudice under FED. R. CIV. P. 41(a) (1) (ii), if all parties to the action consent. See generally 5 Moore, Federal Practice 1007-17 (2d ed. 1951). The right to dismiss "without prejudice" is limited by FED. R. Crv. P. 41. in order to avoid harassment of defendants, see Note, 63 YALE L.J. 738 (1954), since a dismissal without prejudice does not prevent the bringing of subsequent actions on the same claim. Morse v. Bragg, $107 \mathrm{F.2d} \mathrm{648,}$ 649 (D.C. Cir. 1939); Williams v. Mid-South Paving Co., 200 Miss. 103, 25 So. 2d 792, 798 (1946). "With prejudice" means simply that the dismissal is intended to be cffective as res judicata. Harris v. Moye's Estate, 211. Ark. 765, 202 S.W.2d 360 (1947); Malyflower Industries v. Thor Corp., 17 N.J. Super. 505, 86 A.2d 293, 296 (1952).

If the parties specifically agreed to waive future claims arising under the antitrust laws, the consent judgment might be ineffective: courts have frequently held that a consent judgment based upon an agreement that the parties had no power to make is not effective as res judicata. See Kelly v. Town of Milan, 127 U.S. 139 (1888); West v. Bank of Commerce \& Trusts, 167 F.2d 664 (4th Cir. 1948). But cf. Urbino v. Pucrto Rico Ry. Light \& Power Co., 164 F.2d 12 (1st Cir. 1947). 
trust enforcement. ${ }^{65}$ However, it seems far more likely that Laztlor will trap unwary plaintiffs and enable monopolists to evade private enforcement of the law. ${ }^{66}$ The Supreme Court, on certiorari, should reverse Lawlor and remand the case for consideration of the merits of the parties' claims. ${ }^{\text {ot }}$

65. By giving broad prospective effect to consent judgments, Lowlor might encourage litigation in these cases. An injunction is more likely to protect the public interest than a settlement agreement negotiated by the parties with a vicw to protecting their own interests. But see note 52 supra. A better way to protect the public interest in private antitrust cases would be to require court approval of settlements, as is done in the case of class or representative suits and qui tam actions. See 3 Hroore, Fenzen Practice 3551-60 (2d ed. 1948); McLaughlin, Cafacity of Plaintiff-Stochholder to Terminate a Stockholder's Suit, 46 YaLE L.J. 421, 425, 432-35 (1937). See also Informer's Act $\$ 4,12$ Stat. 698 (1863), 31 U.S.C. \$232(b) (1952).

66. Evasion of private enforcement might as a practical matter amount to freedom to violate the antitrust laws with impunity, since the enforcement agencies of the federal government can prosecute only a fraction of the violations reported due to lacl: of adequate appropriations. See Antitrust Law Enforcement by the Fcderal Trade Commission and the Antitrust Division, Department of Justice, H.R REP. No. 3236, 81st Cong., 2d Sess. 75-76 (1951) ; Testimony of H. Graham MForison, Hearings, suspra note 62 , at 15 .

67. Lawlor's petition for certiorari was granted October 14, 1954. 75 Sup. Ct. 42 (1954).

The merits of the case were previously considered on Lawlor's motion for summary judgment in 1951. See Lawlor v. National Screen Service Corp., 99 F. Supp. 180 (ED. $\mathrm{Pa}$. 1951). The district court granted the motion in part, holding that National Screen's exclusive agreements were unlawful per se, but that the conspiracy charge against the other eight defendants had not been established. No final order was ever entered beeause of the difficulty of framing a decree against only one of the defendants. Brief for Appellants, p. 9, Lawlor v. National Screen Service Corp., 211 F.2d 934 (3d Cir. 1954). The 1951 opinion noted the existence of the former judgment, but did not discuss res judieata, which was first raised by defendants in 1953. Ibid. 